\title{
Integration Strategy of Marketing and Supply Chain PT. Semen Indonesia (Persero) Tbk. Holding Company
}

\author{
Deki Zulkarnain \\ Lembaga Amal Zakat Nasional YDSF \\ deki@zakatydsf.or.id
}

Edy Wahyudi

University of Jember

edydata75@gmail.com

\author{
Sasongko \\ University of Jember \\ sasongko.fisip@unej.ac.id
}

\begin{abstract}
This research focuses on exploring the marketing and supply chain integration strategy at PT Semen Indonesia (Persero) Tbk. Holding Company. The status of the state-owned enterprise (SOE) cement industry has dominated the cement market share in Indonesia after the holding strategy, but the data shows that the market share of Semen Indonesia sales has continued to decline. Another problem is that the accumulated cost of revenue has increased sharply, especially since the income growth is not significant, so that gross income has decreased. This research presents integration activities that occur at the corporate and functional level in the marketing and supply chain directorates. The case study method is used in this research to track the integration of marketing and supply chains as an effort to improve the company's sales performance. Data was collected through in-depth interviews in the Marketing Research $\&$ Analysis section of PT Semen Indonesia (Persero) Tbk and secondary data in the form of company annual reports. The results of this study indicate that PT Semen Indonesia (Persero) Tbk integrates marketing and its supply chain through a strategy of unifying the two functions in one directorate. The marketing and supply chain functions at each Operating holding have been revoked, all of them directly managed by the Holding Company. The supply chain is centrally integrated in the form of transportation, distribution and procurement functions. In the marketing aspect, the Holding Company integrates the marketing planning and marketing control and marketing functions as well as the sales function.
\end{abstract}

Keywords: Strategy; Integration; Marketing; Supply Chain; Holding Company

\section{INTRODUCTION}

PT Semen Indonesia (Persero) Tbk, whose initial name is PT Semen Gresik (Persero) Tbk, is one of the cement industries in Indonesia. The company is a holding company of PT Semen Gresik, PT Semen Tonasa, and PT Semen Padang, which are state-owned enterprises (SOEs). The company has dominated the cement market share in Indonesia after the holding strategy. The rising trend of national economic growth received a 
positive response by the cement industry in Indonesia. The growth is quite significant, even the growth trend in 2017 is the highest compared to previous years. Data from the Indonesian Cement Association (ASI) noted that domestic cement sales in 2017 grew by $7.6 \%$ from the previous year or sold cement valued at 66.35 million tons. The increase was triggered by the growth of cement consumption in the infrastructure sector such as the construction of bridges, toll roads, airport expansion, ports, reservoirs, agricultural support facilities, power plants, railroad development, Mass Rapid Transit (MRT), cross border posts, and areas special economy in Merauke with an investment of up to Rp. 61.5 trillion [1]. Meanwhile, sales in the retail sector were still under pressure even though the growth was not so significant, while in the overseas market segment (exports) it increased by 82.7\% from 2016 or sold to 2.93 million tons [2].

This condition turned out to shift the market share of the sales of Semen Indonesia has decreased respectively from 2015 to 2017 by 41.9\%; 41.7\%; and 40.8\% [2]. Another problem is that the accumulated cost of revenue increased sharply in 2016-2017 by $21.7 \%$, moreover revenue growth only grew by $6.43 \%$, causing gross income to drop by $-19.24 \%$. The massive development of other cement industries such as the presence of various cement industries at global, national and local scale has been realized by the marketing research \& analysis section of PT Semen Indonesia (Persero) Tbk (Reza, Interview. 22 April 2019). This was also confirmed by other marketing research \& analysis staff, that "Our market share continues to fall from year to year, not even only in 2017 ... The basic thing is competitors are applying cheap prices and starting the operation of cement factories that used to be still a development process and is supported by massive marketing activities. (Alkindi, Interview. 2 May 2019).

Efforts made by the company to maintain sales performance and minimize the impact of new entrants as described by Alkindi in an interview on May 2, 2019, have also been summarized in the 2017 annual report, which is PTSI implementing a low price strategy. This strategy has resulted in insignificant revenue increases and on the other hand PTSI is unable to cover the cost of goods sold which has increased from the previous year as presented in the 2017 company income statement. They are constantly doing improvements, for example, in marketing aspects, the company has changed the paradigm of sales approach from production focus to customer focus, expanding marketing focus from domestic to regional, diversifying products through developing cement derivative products, expanding bulk market market share, implementing direct selling for retail bags, intensifying the role of Semen Indonesia International, increasing efforts to add variance in types of derivative products, as well as developing marketing communication programs that lead to an increase in perceived quality and engagement with customers [3]. The Company also always strives in creating business synergy that is run, even in response to the decline in the market share of Semen Indonesia, they are trying to centralize marketing strategies in an effort to spur sales performance. The presence of centralize marketing within the operating holding environment, but operational transactions are still carried out by each subsidiary. The merger can be said as an integration of marketing and supply chain but only at certain boundaries. This 
strategy began to be implemented since 2017, the impact is the marketing directorate is managed directly by the holding company. The policy only regulates the company's market share, meaning that the holding divides the target market area into 3 areas. Regional 1, including serving the Sumatra region and surrounding areas; Regional 2, covering Java and Bali as well as Kalimantan Island; Regional 3 covers Kalimantan, Maluku, NTT, Eastern Indonesia.

Centralize has not fully had a significant impact on the company's revenue performance, which is characterized by insignificant growth data. Marketing performance should improve over time, especially since the company has been supported by an integrated supply chain management system, the initiative has been carried out since 2017 in order to encourage the achievement of company performance with the term move closer to costumer which is closer to customers by implementing the Supply system chain Management (SCM). The advantages of supply chain management should be able to sustain marketing performance, through integrated collaboration over the supply chain system, the company is able to increase revenue and or reduce operational costs [5]. These efforts have not yet yielded positive results due to the still high cost of revenue, resulting in a low profit portfolio in 2017. In addition to external constraints, according to Hendi Prio Santoso as PTSI's president director, emphasized that the consolidation process of Semen Indonesia as the holding company or Holding Company (HoldCo) ) with a subsidiary is still ongoing. They still continue to make various efforts so that the performance of the state-owned company which has been integrated into a strong and international class [3].

The Company has held a holding with the birth of the integrated supply chain system in supply chain management (SCM). The supply chain is a combination of companies that have been held. The advantages of implementing supply chain management (SCM) can improve a company's financial performance [6]. SCM has become increasingly important since the early 1990s, although this approach was introduced in the early 1980s [7]. SCM can be defined as managing upstream and downstream relationships with suppliers and customers to provide superior customer value at a lower cost to the entire supply chain [8]. The integration between marketing and supply chain management has been widely recognized for example [9]-[11] which says that the marketing movement has a very significant effect on supply chain management, and vice versa [10]. The marketing strategy will demand a strong supply chain management system [12]. Basically, marketing has seven functions such as consumer analysis, product / service sales, product / service planning, pricing, distribution, marketing research, and opportunity analysis [13], Therefore, the integration of these two functions should have been able to drive the performance of corporate sales and the resulting maximum profit because it is supported by integrated supply chain systems in all operating holding and holding companies themselves.

Based on the description above, there are obstacles faced by the company from 2015 to 2017. The researcher mapped them into two sides, namely on the internal and external sides. On the external side, the higher level of competition, the higher cost of 
raw materials and energy causes limited market absorption, so that sales are not so significant and have an impact on the decline in the company's financial portfolio. On the internal side, the company is still in the process of consolidating between Semen Indonesia as a holding company with a subsidiary or operating company. Integration has been done but has not shown significant performance in the company on revenue. The research aims to explore, analyze and provide a descriptive of the integration and its implications for company sales.

\section{LITERATURE REVIEW}

\section{A. Marketing Policy and Strategy}

Business policies are guidelines developed by an organization to regulate business actions, by defining boundaries where business decisions must be made [14]. Business policies include guidelines, rules and procedures established to support efforts to achieve organizational goals [15]. Guidelines are a collection of basic provisions that give directions or instructions on how something should be done [16]. Business policies also include various policies governing human resources (HR), production and operations, finance, and marketing. These policies are usually known as functional policies. Other types of policies, in addition to these levels there are also policies at the organizational level to the business unit. Marketing policies are guidelines, rules and procedures established to support efforts to achieve organizational goals through the marketing function. Likewise with other business functions that have policy guidelines in order to achieve organizational goals. Marketing strategy is a plan that sets out the company's expectations of the impact of various marketing activities or programs on the company's product demand [17]. Marketing strategies are grouped into two aspects namely marketing strategy formulation and marketing strategy implementation [18], [19]. The marketing strategy formulation process is built on three pillars, namely customers, companies and competitors.

\section{B. Integration}

Integration is defined as the merging of different activities, programs or hardware components into one functional unit [20], [21]. The merger is intended to be able to work together or form an integrated unit which is commonly known as vertical and horizontal integration. Integration can be marked by the existence of cooperative relationships, collaboration, and coordination in different groups with the aim of optimizing the achievement of company goals [22], [23]. deally, the integration states the company's internal and external relations with other companies.

Integration is divided into two parts, namely internal and external integration [22], [24]-[27]. nternal integration is an effort to synchronize operational flow through existing policy guidelines in the organization [26], [28]. The integration is done through comprehensive integrated planning and control efforts in the organizational system [27]. Basically the use of this internal integration strategy is an effort to eliminate the traditional functional "silo mentality" and emphasize better coordination 
between functional areas (cross-functional) [24], [25]. Whereas external integration is an integration carried out in an effort to synchronize logistics competencies with certain offerings in the supply chain for service improvement at lower total supply chain costs [28]. Synchronizes internal supply chains with customers and suppliers [27] or also commonly referred to as cross-organizational integration.

\section{Integration Strategy}

Integration strategies can be in the form of open market negotiations, cooperation, coordination, and collaboration [29]

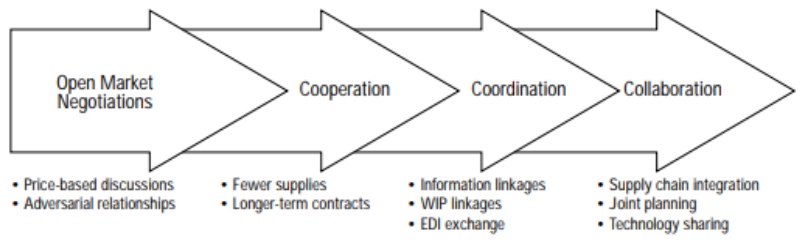

Figure 1. Integration Level

Figure 1 illustrates four types of integration strategies that range from open market negotiations to collaboration strategies. The more directed towards the right, the higher the integration level of the relationship strategy and vice versa, the more to the left of the use of the strategy, the lower the level of relationship and complexity. Open market negotiations describe normal and pure relationships that occur because there are transactions between companies. In this type of relationship there is no joint commitment in the operational domain, so when the transaction ends, the relationship ends [29]. Cooperation has the characteristic that the organization uses a small number of suppliers with a long-term cooperation contract. On the internal aspect, cooperation views these units as interdependent parts in meeting customer needs as end users [29]. At the level of coordination strategy an increase in the intensity of the relationship occurs. These conditions allow workflow coordination and information to be determined in a system that is used together, for example in electronic data interchange systems (EDI systems) or the use of just in time (JIT) [29]. While collaboration strategy is a picture of relationships that have the characteristics that between one organization and another have the same strengths and they carry out planning activities, implementation, and evaluation together such as logistics, product planning, product marketing, and various other strategic plans [29], [30].

\section{Marketing Integration}

In the marketing concept there are three main elements, namely customer orientation, profit orientation, and integrated efforts [31]. When related to other concepts, the three elements above also contain an effort to balance between the company's profit goals and the needs of its customers [32]. Keith Crosier [17] has examined various marketing definitions and grouped them into three domains. These domains include marketing as a process, concept or business philosophy, and orientation. Various definitions related to marketing are not contradictory, but have a complementary tendency. The American 
Marketing Association (AMA) defines marketing as an organizational function and a series of processes creating and conveying value to customers and managing relationships with customers so as to provide benefits to the organization and its stakeholders [17].

ntegration in marketing is important in sustaining company performance, especially for companies that do mergers [33]. Marketing integration is also one of the marketing strategies used in achieving company goals [34]. Domain integration can be in the form of marketing systems, structures, activities, and marketing processes. The success of integration can be seen if all the differences in the company's marketing approach are harmonized [35].

\section{E. Supply Chain Integration}

Supply chain or supply chain is a distribution system for the distribution of goods or services from suppliers to customers involving several actors [8], [36], [37]. These actors include suppliers, procurement, operations, distributions, and costumers [8]. his can be seen in the following illustration:

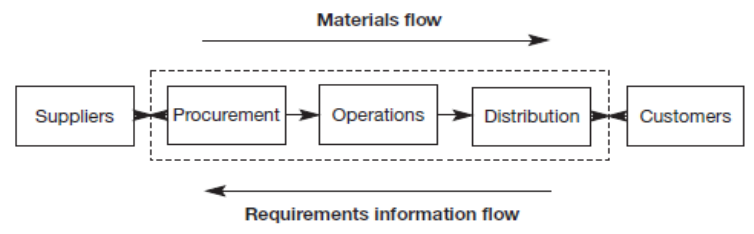

Figure 2. Supply chain process

The existence of actors in the above system really needs to be managed in order to build quality services to get the lowest possible cost. Thus, supply chain management is expected to meet customer needs. On the other hand, the supply chain flow above also illustrates product flows, information flows, and financial flows that are simultaneously moving [8], [38], [39]. Product flow is related to the movement of goods or services from suppliers to customers, while information flow involves transmitting messages and updating the status of orders from suppliers to customers or vice versa. Financial flow is the flow of payments, ownership arrangements for goods or services that flow from customers to suppliers.

The supply chain in the conventional view has a tendency to stand alone among other business functions [8]. However, now that view has been realized by various companies, and they realize that the real competition is not between the company and the company but the supply chain against the supply chain. This then makes a shift in the business paradigm of supply chain management. These changes are about supply chain integration, as illustrated in the following figure [40].

In the initial phase, the supply chain is supported by a variety of business functions and their respective parts stand alone, so that all processes are isolated from each part of the function, while the next phase of integration of functions and their parts has begun to form, but is still quite limited only n certain parts only distribution and procurement management 


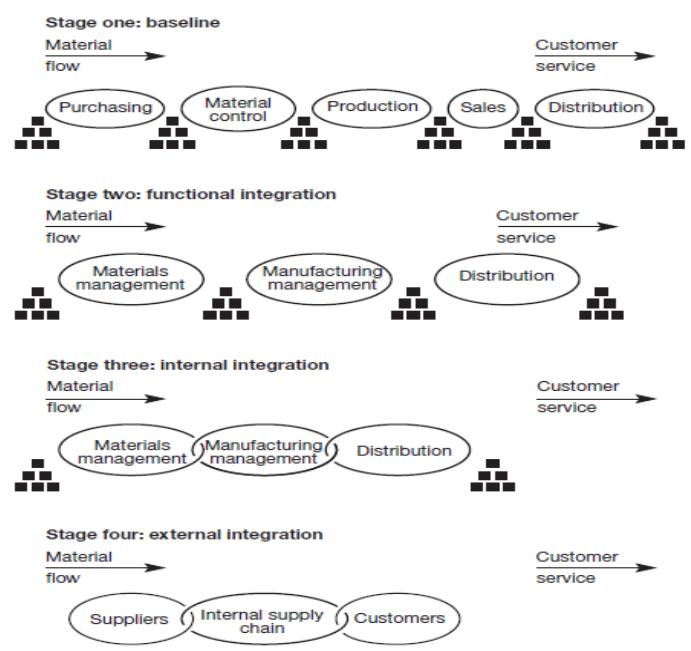

Figure 3. Supply chain integration process

Only then in the third phase, integration is formed in the company's internal supply chain but still isolated from the supply chain connected outside the company (external). The fourth phase that was described earlier is that now the company has realized that the business battle is the supply chain against the supply chain. It is at this stage that the integration is perfectly formed, both from the external and internal sides (suppliers, internal supply chains, and customers).

The supply chain integration process requires two key components that are so important namely connectivity and simplification [22]. Both components are present based on various literatures on supply chain integration [22], [41]-[45]. Connectivity emphasizes relationships between suppliers, operations and customers. This relationship explicitly helps companies to get the right information and build collaboration from various parties, both internal and external to the company [41]. Another key component is simplification as the elimination of functions in processes that are considered less relevant and excessive in business processes [43]. This allows the re-engineering of business processes to achieve efficiency and effectiveness.

\section{F. Marketing and Supply Chain Integration}

The study of integration between marketing and supply chain in the context of holding companies becomes a new domain in the object of cross-functional integration studies. Although research that addresses the integration of marketing and supply chain has been widely studied[12], [23], [26], [46]-[48]. Both of these functions have indeed become one of the spearheads of the company in generating competitive advantage. Both are related to creating needs and fulfilling requests. This function does have characteristics that require direct contact with external parties both suppliers and customers [8], even the relationship between marketing and supply chains has a positive effect on organizational performance [49], [50]. Alignment in the two functions is so important, especially in building the company's customer satisfaction and is the key to the success of a company's profitability and sustainable competitive advantage[51]. 
Marketing activities are basically an institutional process to create communication, delivery, exchange of offers that have value for customers, clients, partners, and society in general [52]. Demand will be created in marketing activities through product promotion activities with appropriate pricing based on market segments, while on the fulfillment of demand (supply) through distribution activities that are supported by the distribution network. In essence, marketing activities focus on creating requests. On another aspect, specific studies relating to meeting demand are about supply chains. This is confirmed [53], that the supply chain (logistics system) exists as a discipline that focuses on supplying requests. The supply chain is responsible for the product source flow until it is delivered to the end customer with the principle of lower costs, higher quality, more flexibility and faster response times [8].

Coordination and collaboration become very important for marketing and other business functions in building an organization's competitive advantage. Competitive advantage is the extent to which an organization is able to create a position that can be maintained over its competitors [54]. In general, competitive advantage in organizations shows capabilities such as lower prices, shorter delivery times, high flexibility. All of these capabilities are positively influenced by marketing and supply chains [55].

Porter's value chain [56] has described five main activities namely inbound logistics, operations, outbound logistics, marketing, and service. There are only two core activities, namely supply chain (inbound logistics, operations, outbound logistics) and marketing. Its activities are a form of service to customers. The supply chain and marketing functions are related to the company's efforts to create value. These two functions are very important to integrate to maximize value creation.

The integration effort between marketing and supply chain is based on the porter niai chain [56] and specific views about the supply chain [8]. The integration of the two has also been included in the interactive model [55] as follows,

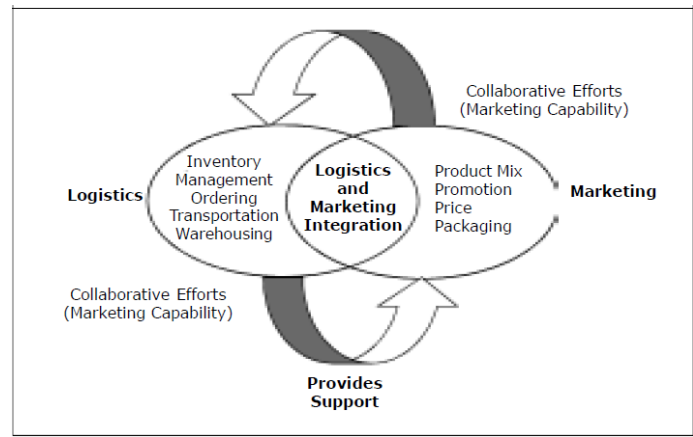

Figure 1 Logistics and marketing integration : an interactive model

Model The integration in Figure 4 is an attempt to synchronize the marketing mix (product, promotion, price, packaging) and the logistics mix (warehousing, order management, transportation, warehousing) to achieve the level of customer satisfaction. The dependence between marketing activities and logistics activities is 
also an illustration of the model above by hinting that it is very important to coordinate and collaborate in building customer satisfaction.

\section{G. The concept of Indonesian BUMN Holding Company}

Establishment of SOEs Holding as a government effort to increase BUMN value creation [57]. In addition, the formation of holding also serves as an alternative basis for rightsizing which is considered to be quite a number of SOEs in Indonesia to reach 117 companies so as to cause a very broad span of control as well. The transformation of SOEs into a Holding Company strategy becomes a demand in the current situation of global competition. Creating productivity and efficiency is very important. Stateowned business entities or abbreviated SOEs are defined in Law No. 19 of 2003 as a business entity whose entire or most of its capital is owned by the state through direct participation that comes from separated state assets. As a dominant business actor in many developing countries, including in Indonesia.

Holding as a strategy of merging companies from various business lines in the form of a parent company. Holding Companies at least control the dominant interest in one or more other companies so that it is possible to dictate their policies through the power of votes [58]. he concept of Indonesian SOEs Holding Company Establishment of SOEs holding as a government effort to increase SOEs value creation[57]. In the field of strategy management, holding companies or corporate parenting strategies are at the level of corporate strategy (Corporate Level Strategy) at the level of business strategy [57]. The strategy at this level (Corporate Level Strategy) focuses on determining the business owned and will be run by the company. In addition, there are also strategies at the business and functional unit level [59].

In the course of research on the holding company strategy and corporate parenting, there are several typologies or models of the implementation of holding strategy management [60], among them as follows:

1. Hands-off Ownership

This typology has a tendency that the parent company only manages the subsidiary through financial assets only. Not too intervening in the strategic and operational aspects of its subsidiaries.

2. Finacial Sponsorship

This typology has a tendency to take advantage of financial aspects. The formation of holding makes it very easy for subsidiaries to get access to external funding.

3. Sinergy Creation

The holding strategy is intended to improve sales, marketing, human resource and operational talent among the subsidiaries. The position of the parent company does not interfere in the strategic and operational matters of its subsidiaries.

4. Strategi Guidence 
Subsidiaries will always follow the strategic direction of the parent company. The position of the parent company is a strategic policy maker for the subsidiary companies.

5. Functional Leadership

This strategy focuses on sharing resources between subsidiaries. The strategy is to strengthen the development of excellence of each function at the corporate level. They will focus on strategic business growth, innovation, and investment issues in the context of the sustainability of their business.

6. Hands-on Management

The involvement of the parent company's management is very high and active in making operational decisions of subsidiaries, not just determining the direction of the strategy (Guidance Strategy), even financial targets to other functional policies

The legal basis that has been used as the foothold for holding SOEs is PP No. 72 of 2016 (Amendments to Government Regulation No. 44 of 2005 concerning procedures for the inclusion and administration of state capital in SOEs and limited liability companies). In addition, other key footholds such as Law No. 19 of 2003 concerning SOEs, Law No. 40 Regarding Limited Liability Companies, Law No. 17 of 2007 concerning state finances

\section{RESEARCH METHODS}

This study uses a qualitative paradigm with a case study method in analyzing integration strategies in marketing and supply chains as an effort to improve the company's sales performance. Data was collected through in-depth interviews in the Marketing Research \& Analysis section of PT Semen Indonesia (Persero) Tbk. The informant was determined purposively based on certain considerations. Secondary data is traced from company documents in the form of annual reports, company catalogs, and physical devices such as cement products that they have packaged. These data, the analysis researchers based on the evidence analysis strategy by developing case descriptions, dominant analysis with patterned relationships. The validity of the data in this study was tested using perseverance, source triangulation, and peer examination..

\section{FINDINGS AND ARGUMENTS}

\section{A. Marketing and Supply Chain Integration PT Semen Indonesia (Persero) Tbk}

The results of this study found the integration of marketing and supply chains of PT Semen Indonesia (Persero) Tbk through the strategy of uniting the two functions in one directorate known as the directorate of marketing and supply chain. The lines of communication and decision making are getting shorter. There is no longer any formulation activity, implementation, and evaluation of marketing strategies in each 
operational holding (OpCo). All these activities have been taken over by PTSI. The marketing unit at PTSI handles marketing planning and control activities, sales in regional I, II, and regional III. The supply chain unit handles the distribution department and the transportation department, while the procurement function in the procurement department becomes a separate department without a directorate and the coordination is directly with the director of PTSI. All of them coordinate with regards to online data-based IT systems such as SAP (System Application Product) which contains all the target data, sales, production needs, and reports summarized in the system. Coordination between OpCo and HolCo and between departments within the holding company is formed through the collaboration of the PTSI IT system.

Integrating cross-functional work activities and departments of an organization can be in the form of open market negotiation, cooporation, coordination, and collaboration (Spekman et al., 1998). This integration pattern is called the level of integration. PTSI, in carrying out its business operations in marketing and supply chain always coordinate in the form of monthly meetings between departments and between units. The activity is an integration effort at the coordination level. The goal is to be able to integrate movements between each department and unit. They use ERP-based information technology (IT) at an advanced level referring to the COBIT and ITIL framework and the SOE Information Technology Guidelines Per-03 / MBU / 02/2018. The IT makes HolCo and OpCo coordinate with each other in various activities such as marketing and supply chains. Coordination in marketing activities such as marketing intelligence, demand planning, sales, channel management, customer profile, customer loyalty, promotion programs, social media, e-commerce), while coordination in supply chain activities such as purchasing, warehousing, transportation, distribution and delivery. The company policy has centralized management (IT) at HolCo, while OpCo is the IT user. This type of integration is at the coordination level. IT is used in order to coordinate between customer demand and fulfill the needs of Semen Indonesia customers, in addition to the internal aspects they are used to measure the success of its business. Another integration with the centralized supply chain mechanism and also directly managed PTSI makes it easy for them to manage the supply chain scheme in all HolCo. The integration is in the form of attracting distribution and transportation functions and work units to the Semen Indonesia holding. Both of these supply chain functions are perfectly integrated with marketing. The impact, they get the efficiency of operational costs on consolidation to the expeditor / transproter and distribution facilities. This strategy is better known as the lowest cost highest margin. Other integration activities through joint ventures in several projects between HolCo and OpCo. his scheme is a joint venture that tends to support product supply activities, such as the consolidation of the birth of PT Semen Kupang Indonesia, PT Semen Gresik, PT Krakatau Semen Indonesia, and various other activities such as the establishment of Grinding Plants, Packing Plants and Supporting Facilities. This joint venture activity lasts not long enough in order to meet customer needs based on their 
target market area, so that its activities are categorized as an integration strategy at the coordination level.

PTSI as a strategic holding that continues to move in strengthening the foundation of synergy of HolCo and OpCo activities in a job. The basis for integration in functional and business units lies in the integration of the company [7], that's what happened to PTSI. The integration of PTSI marketing and supply chain functions in one directorate is seen as a form of alignment and effectiveness of the company's business activities. The relationship of marketing and supply chain always looks at two interests namely in the marketing perspective of marketing strategies in the formulation of demand, as according [18], [19] in the formulation strategy activities are built on the pillars of customers, companies, and competitors which are usually contained in the process of positioning, segmenting, and targeting. The supply chain perspective certainly involves logistical and distribution factors. The conclusion that the emphasis on creating a marketing perspective, while demand in the supply chain perspective more emphasis on meeting the demand.

Marketing management includes strategy formulation, strategy implementation, and strategy evaluation [18]. The point is creating demand through efforts to create value in the form of products and prices, communicating that value in the form of promotions through communication channels based on segments and targets. Demand is fulfilled through the supply chain planning process, supply chain design, and supply chain operations [46]. Convergence between the creation of requests and the fulfillment of requests, of course, must always be coordination and collaboration. Both are very encouraging the creation of value to customers.

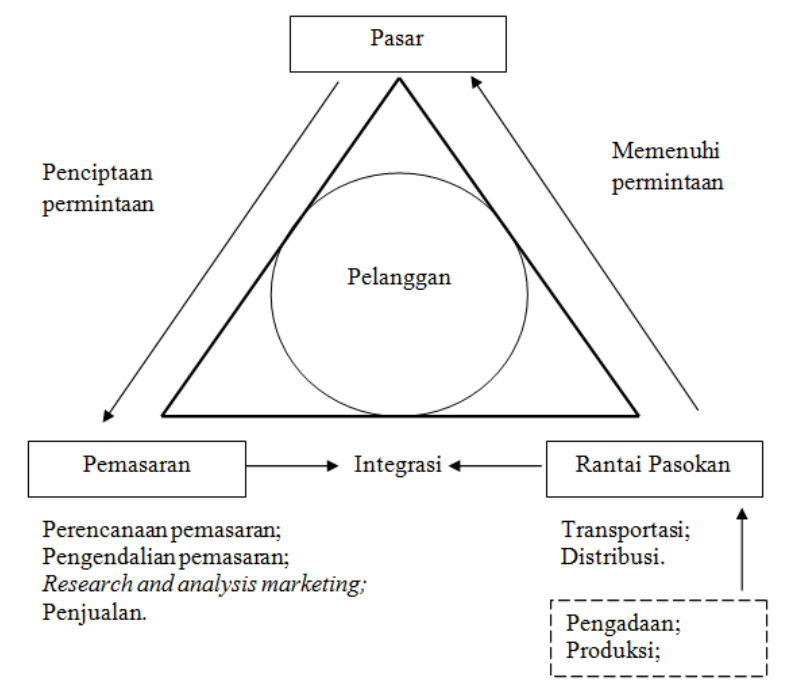

Figure 2 Logistics and marketing integration : an interactive model

When the marketing planning and control division segmentes the target market area and calculates it in the PTSI target market, it must be collaborated with the readiness of the distribution and transportation departments of the supply chain unit in order to create services to meet consumer demand. Likewise, when PTSI's marketing research and analysis department calculates the people's purchasing power related to 
cement products, they will coordinate with the procurement department, the production department, and the supply chain unit to find optimal costs to produce prices according to people's purchasing power. This has just happened to PTSI as a holding company, when some functions are drawn to the holding company and only two functions are left in each OpCo, financial and production. This has led to the integration of functions between HolCo and OpCo.

The integration commanded by PTSI between marketing and supply chains is packaged in one directorate at the holding company. The strategic policy holder is under the control of PTSI. Market demand tends to be formed by PTSI, while OpCo and other subsidiaries tend to encourage the fulfillment of market demand needs. This position is in the perspective of the supply chain which places more emphasis on meeting demand. Both perspectives illustrate the interdependence of marketing and supply chains.

Marketing will need supply chain activities to deliver consumer demand to the order location, while supply chains need marketing activities so that their products are absorbed by the market. Such dependence has indeed been in the spotlight for example [48] highlight the dependence of logistics and marketing activities. The dependency also encourages the formation of cross-functional integration. PTSI also realized this through its integration efforts. This pattern is illustrated in the framework of marketing and supply chain integration adopted from [55] As Figure 4.5. The integration framework is basically an effort to synchronize the marketing mix (product, promotion, price, packaging) and the logistics mix (warehousing, order management, transportation, warehousing) to achieve the level of customer satisfaction. Porter Chain [56] also concluded that of the five main activities in an effort to build competitive advantage, but basically there are only two namely the supply chain (inbound logistics, operations, outbound logistics) and marketing. Its activities are a form of service to customers. The function of the supply chain and marketing is related to the company's efforts in creating value. These two functions are very important to integrate to maximize value creation.

Demand creation is an effort of the company in order to understand market needs, what must be made, and how to sell and where to sell. PSTI carries out marketing planning and control activities, and executes the results of the planning in the form of sales activities. In theory, (Armstrong, Adam, Denize, \& Kotler, 2014) marketing is a series of institutional process activities to create communication, delivery, offer exchanges that have value for customers, clients, partners, and society in general [52]. Marketing in the process will involve the formulation of marketing strategies (segmentation, targeting, differentiation, positioning, creating communication and providing value to customers so as to produce customer satisfaction and loyalty) and the implementation of marketing strategies executed by marketing programs through the marketing mix [18].

Fulfilling demand is the process of providing and delivering needs to the market by emphasizing lower costs, higher quality, more flexibility and faster response times 
[40]. This emphasis can be achieved with a quality supply chain system. The supply chain is a picture of product flows, information flows, and financial flows that move simultaneously. The supply chain in the process requires strategic planning, design and operation of the supply chain to meet demand. PTSI has integrated the supply chain in all its entities such as procurement, production, packing plants, transportation, and distribution. However, technological differences are not all OpCo is able to produce the same quality, it has been anticipated by the construction of packing plants in various target market areas. Of course, this also needs attention in order to help equalize production technology so that all product quality in each region is fulfilled in order to fulfill demand based on the quality and type of product.

Collaboration between marketing and supply chain at PTSI according to the author's perspective in order to reduce operational costs (in the PTSI cost transformation strategy) after setting the target market into three regions, PTSI then develops supply chain solutions in order to achieve a massive target market, its superiority is able to serve various products with lower costs and faster response times. This was also supported by a centralized procurement mechanism, thereby strengthening the company's competitiveness, especially in the pricing system aspects created by the PTSI Marketing unit for all types of products. What's more, OpCo is directed at a production focus strategy in order to deliver higher quality.

\section{B. The implication to the sale of PT Semen Indonesia (Persero) Tbk}

The core of integration activities are both related to demand created through marketing activities while supply chain activities are needed in meeting market demands by emphasizing lower costs, higher quality, more flexibility and faster response times. The interrelationship between all the processes of creating and fulfilling demand further strengthens the integration of marketing and supply chains, the ultimate goal of creating a competitive advantage for the company [51], [56].

The supply chain contributes to customer service which is also part of the marketing concept [55]. These services can lead to whether or not consumers are satisfied so determine whether they make repeated purchases or not. The integrated supply chain has facilitated PTSI's marketing activities in order to meet customer needs in all target market regions. The integration of both leads to the creation of value to customers, the building of satisfaction and loyalty and ultimately will increase overall profits and company growth [12]. Although PTSI's sales growth has not been very significant in 2017-2016; 2015 [2] according to the data in the introduction to this article. The data is a picture of performance at the beginning of integration, but on the other hand, in 2018 [61] evenue from sales increased and was followed by a decrease in the company's operating expenses, so that the company's profit rose by $71.2 \%$ from the previous year which had a decline in profit of $-45.5 \%$. illustrates that the integration effort has slowly produced more effective and efficient results than before. The implication on product sales has given positive results and is able to reduce the cost of goods sold so that the company gets an increase in revenue. So, the management of 
marketing activities must always accommodate all the target market areas that they have geographic-based segmentation to enlarge the company's sales that have been supported by an integrated supply chain system.

\section{CONCLUSION}

Research shows that PT Semen Indonesia (Persero) Tbk integrates its marketing and supply chain through a strategy of unifying the two functions in one directorate. The function of marketing and the supply chain in each OpCo has been revoked, all of which are directly managed by HolCo centrally.

The supply chain is centrally integrated in the form of transportation, distribution and procurement functions. In the marketing aspect, HolCo integrates marketing planning and marketing control and marketing functions as well as sales functions. The integration aims to create a company's competitive advantage. The implication on product sales has given positive results and can reduce the cost of goods sold so that the company gets an increase in revenue.

\section{REFERENCES}

[1] KPPI, "Evaluasi Proyek Strategis Nasional (PSN)," Kementerian Koordinator Bidang Perekonomian Republik Indonesia, Jakarta, Infografis, 2017.

[2] P. Semen Indonesia, "Laporan Tahunan 2017," PT Semen Indonesia (Persero) Tbk, Gresik, Annual Report, 2018.

[3] P. Semen Indonesia, "Laporan Tahunan 2017," PT Semen Indonesia (Persero) Tbk, Gresik, Annual Report, 2018.

[4] P. Semen Indonesia (Persero), "Laporan Tahunan 2017," PT Semen Indonesia (Persero) Tbk, Gresik, Annual Report, 2018.

[5] J. Heizer and B. Render, Manajemen Operasi: Manajemen Keberlangsungan Dan Rantai Pasokan. Salemba Empat, 2015.

[6] D. A. Puryono, Mustafid, and F. Jie, "Penerapan Green Supply Chain Management Untuk Peningkatan Kinerja Keuangan Perusahaan," Jurnal Sistem Informasi Bisnis, vol. 6, no. 2, pp. 154-163, 2016.

[7] U. Jüttner, M. Christopher, and J. Godsell, "A strategic framework for integrating marketing and supply chain strategies," The International Journal of Logistics Management, vol. 21, no. 1, pp. 104-126, 2012.

[8] M. Christopher, Logistics \& supply chain management, 4. ed. Harlow: Financial Times Prentice Hall, 2011.

[9] R. R. Lummus, K. D. Leslie, and R. J. Vokurka, "The impact of marketing initiatives on the supply chain," Supply Chain Management: An International Journal, vol. 8, no. 4, pp. 317-323, 2006.

[10] P. M. Madhani, "SCM and Marketing Management: Mutual Integration," SCMS Journal of Indian Management, vol. 7, no. 2, pp. 16-24, 2010. 
[11] J. T. Mentzer, T. P. Stank, and T. L. Esper, "Supply Chain Management and its Relationship to Logistic, Marketing, Production, and Operation Management," Journal of Business Logistic, vol. 29, no. 1, pp. 1-46, 2008.

[12] D. J. Flint, "Strategic marketing in global supply chains: Four challenges," Industrial Marketing Management, vol. 33, pp. 45-50, 2004.

[13] F. R. David, Strategic Management, 12 th ed. New Jersey: Pearson Education Limited, 2009.

[14] F. Afiff, "Kebijakan Bisnis," Business artikel management, 2015. [Online]. Available: https://sbm.binus.ac.id/2015/01/17/kebijakan-bisnis-bagian-1/. [Accessed: 21-Jul2019].

[15] S. Divekar, "Business policy \& strategic management," India, 2014.

[16] S. Ebta, “KBBI,” Kamus Besar Bahasa Indonesia (KBBI) Kamus versi online. 2019.

[17] F. Tjiptono and G. Chandra, Pemasaran Strategik: Mengupas Pemasaran Strategik, Branding Strategik, Costumer Satisfaction, Strategi Kompetitif, hingga e-Marketing, 2nd ed. Andi Yogyakarta, 2012.

[18] A. I. El-Ansary, "Marketing strategy: taxonomy and frameworks," European business review, vol. 18, no. 4, pp. 266-293, 2006.

[19] A. Ferdinand, "Marketing Strategy Making: Proses \& Agenda Penelitian," Jurnal Sains Pemasaran Indonesia (Indonesian Journal of Marketing Science), vol. 1, no. 1, pp. 1-22, 2002.

[20] M. A. Birkin, Building the Integrated Company. England: Gower Publishing Limited, 2000.

[21] Businessdictionary, "Definition integration." WebFinance Inc., Austin, 2019.

[22] H. Chen, P. J. Daugherty, and A. S. Roath, "Defining And Operationalizing Supply Chain Process Integration," Journal Of Business Logistics, vol. 3, no. 1, pp. 63-84, 2009.

[23] A. E. Ellinger, S. B. Keller, and P. J. Daugherty, "The relationship between marketing/logistics interdepartmental integration and performance in US manufacturing firms: An empirical study," Journal Of Business Logistics, vol. 21, no. 1, pp. 1-22, 2000.

[24] C. Gimenez, "Logistics integration processes in the food industry," International Journal of Physical Distribution \& Logistics Management, vol. 36, no. 3, pp. 231-249, 2006.

[25] C. Gimenez and E. Ventura, "Logistics-production, logistics-marketing and external integration: their impact on performance," International journal of operations e Production Management, vol. 25, no. 1, pp. 20-38, 2005.

[26] H. Hulthén, "On understanding of external and internal integration in supply chains: challenges and evaluation," Lund University, 2016.

[27] G. C. Stevens, "Integrating the supply chain," international Journal of physical distribution \& Materials Management, vol. 19, no. 8, pp. 3-8, 1989. 
[28] A. M. Rodrigues, T. P. Stank, and D. F. Lynch, "Linking strategy, structure, process, and performance in integrated logistics," Journal of Business logistics, vol. 25, no. 2, pp. 65-94, 2004.

[29] R. E. Spekman, J. W. Kamauff Jr, and N. Myhr, "An empirical investigation into supply chain management: a perspective on partnerships," Supply Chain Management: An International Journal, vol. 3, no. 2, pp. 53-67, 1998.

[30] A. Ajmera and J. Cook, "A multi-phase framework for supply chain integration," SAM Advanced Management Journal, vol. 74, no. 1, pp. 37-49, 2009.

[31] R. O'Leary and I. Iredale, "The marketing concept: quo vadis?," European Journal of Marketing, vol. 10, no. 3, pp. 146-157, Mar. 1976.

[32] P. J. Hovell, "The Marketing Concept and Corporate Strategy," Manajemen Decesion Joournal, vol. 17, no. 2, pp. 157-167, 1979.

[33] J. P. Workman Jr, C. Homburg, and K. Gruner, "Marketing organization: an integrative framework of dimensions and determinants," Journal of Marketing, vol. 62, no. 3, pp. 2l-4l, 1998.

[34] Maxmanroe, "Strategi Pemasaran: Pengertian, Fungsi, Tujuan, Konsep, dan Contohnya," Marketing, 2019. [Online]. Available: https://www.maxmanroe.com/vid/marketing/pengertian-strategipemasaran.html.

[35] C. Homburg and M. Bucerius, "A marketing perspective on mergers and acquisitions: How marketing integration affects postmerger performance," Journal of Marketing, vol. 69, no. 1, pp. 95-113, 2005.

[36] A. P. Irawan, Buku Ajar Manajemen Rantai Pasokan. Jakarta: Universitas Taruma Negara, 2008.

[37] D. Lu, Fundamental of Supply Chain Management. Kenya: Ventus Publishing, 2011.

[38] D. Apriyani, R. Nurmalina, and Burhanuddin, "Evaluasi Kinerja Rantai Pasok Sayuran Organik dengan Pendekatan Supply Chain Operation Reference (SCOR)," Jurnal Ilmiah Manajemen, vol. 8, no. 2, pp. 312-335, 2018.

[39] M. P. Tampubolon, Manajemen Operasi dan Rantai Pemasok. Jakarta: Mitra Wacana Media, 2018.

[40] M. Christhoper, Logistics \& Supply Chain Management: creating value-adding networks, Fourth Edition. Great Britain: Pearson Education Limited, 2011.

[41] D. J. Closs, M. Swink, and A. Nair, "The role of information connectivity in making flexible logistics programs successful," International Journal of Physical Distribution \& Logistics Management, vol. 35, no. 4, pp. 258-277, 2005.

[42] S. E. Fawcett and G. M. Magnan, "The rhetoric and reality of supply chain integration," International Journal of Physical Distribution \& Logistics Management, vol. 32, no. 5, pp. 339-361, 2002.

[43] M. T. Frohlich and R. Westbrook, "Arcs of integration: an international study of supply chain strategies," Journal of operations management, vol. 19, no. 2, pp. 185-200, 2001. 
[44] K. B. Kahn and J. T. Mentzer, "Marketing's integration with other departments," Journal of business research, vol. 42, no. 1, pp. 53-62, 1998.

[45] M. Pagell, "Understanding the factors that enable and inhibit the integration of operations, purchasing and logistics," Journal of operations management, vol. 22, no. 5 , pp. 459-487, 2004.

[46] H. Danmei, "Integration of Supply Chain Management and Marketing-Case Study of a Swedish Fashion Retailer," University of Gothenburg, Gothenburg, 2016.

[47] S. Min and J. T. Mentzer, "The role of marketing in supply chain management," International journal of physical distribution \& logistics management, vol. 30, no. 9, pp. 765-787, 2000.

[48] G. Svensson, "Supply chain management: the re-integration of marketing issues in logistics theory and practice," European Business Review, vol. 14, no. 6, pp. 426-436, 2002.

[49] A. Alavi, M. Faryabi, and S. K. Sadeghi, "The Impact of Marketing Strategy Alignment on Supply Chain Performance," British Journal of Economics, Management \& Trade, vol. 4, no. 9, pp. 1356-1375, 2014.

[50] K. W. Green Jr, D. Whitten, and R. A. Inman, "The impact of aligning marketing strategies throughout the supply chain," Sam Houston State University, Huntsville, TX, 2008.

[51] U. M. Remmel, "Integration of marketing and logistics: a way to competitive advantage in South Africa," International Journal of Physical Distribution \& Logistics Management, vol. 21, no. 5, pp. 27-31, 1991.

[52] G. Armstrong, S. Adam, S. Denize, and P. Kotler, Principles of marketing. Pearson Australia, 2014.

[53] D. M. Lambert, M. C. Cooper, and J. D. Pagh, "Supply chain management: implementation issues and research opportunities," The international journal of logistics management, vol. 9, no. 2, pp. 1-20, 1998.

[54] M. E. Porter and M. R. Kramer, "The competitive advantage of corporate," 2002.

[55] P. M. Madhani, "Logistics and marketing integration: enhancing competitive advantages," The IUP Journal of Management Research, vol. 16, no. 3, pp. 7-29, 2017.

[56] M. E. Porter, Competitive advantage of nations: creating and sustaining superior performance. simon and schuster, 2011.

[57] T. Pranoto, Holding Company BUMN : Konsep, Implementasi, dan Benchmarking. Jakarta: LM-FEB UI, 2017.

[58] H. C. Black, "Holding Company," Black's Law Dictionary. West Publishing Co., ST Paul Minn, p. 941, 1968.

[59] F. R. David, Manajemen Strategis : Konsep, Edisi 12-Buku 1. Jakarta: Salemba Empat, 2012.

[60] M. Kruhler, U. Pidun, and H. Rubner, First Do no Harm: how to be a corporate parent. USA: BCG, 2012. 
[61] P. Semen Indonesia, "Laporan Tahunan 2018," PT Semen Indonesia (Persero) Tbk, Gresik, Annual Report, 2019. 